Saudi Journal of Business and Management Studies Abbreviated Key Title: Saudi J Bus Manag Stud ISSN 2415-6663 (Print) |ISSN 2415-6671 (Online) Scholars Middle East Publishers, Dubai, United Arab Emirates Journal homepage: https://saudijournals.com/sibms

Original Research Article

\title{
The Effects of External Pressure, Management Commitment, and Human Resources Competence on Financial Reporting Transparency (Study on Regional Work Unit Tangerang District)
}

Jafril Yudin", Wiwik Utami

Universitas Mercu Buana Indonesia

DOI: $10.36348 /$ sjbms.2020.v05i07.001

| Received: 16.03.2020 | Accepted: 23.03.2020 | Published: 08.07.2020

*Corresponding author: Jafril Yudin

\section{Abstract}

The purpose of this study is to analyze whether Financial Reporting Transparency can be influenced by External Pressure, Management Commitment and HR Competency by using several indicators in SKPD Tangerang District. Based on empirical results from the questionnaire data distributed, this study found: (1) 1 variable related to the application of financial reporting transparency, significantly related to the weak budget report information presented in published financial statements; (2) 2 other variables namely management commitment and HR competence were not found to be significantly related to the implementation of transparency. Finally, our findings show that pressures from government regulations, political factors and the obligation to use online technology that are considered too open to the public have been proven to influence financial report makers for transparency.

Keyword: External Pressure, Management Commitment, Human Resources Competence, Financial Reporting

Transparency.

Copyright @ 2020: This is an open-access article distributed under the terms of the Creative Commons Attribution license which permits unrestricted use, distribution, and reproduction in any medium for non-commercial use (NonCommercial, or CC-BY-NC) provided the original author and source are credited.

\section{INTRODUCTION}

Today society demands transparency in financial management carried out by government agencies. APBN / APBD that has been designed so neatly by the government, but in terms of their use must be open and transparent to the public. It is intended that the public and the government together supervise, evaluate and support each other to realize awareness of the development of a more developed country.

The obligation to apply information transparency among government organizations arises because it is regulated in government regulations which are a responsibility to the public, as stipulated in Law Number 33 of 2004 article 66 paragraph 1 (2004), Regional Finance is managed in an orderly manner, obedient to the laws and regulations. invitation, efficient, economical, effective, transparent, and responsible with due regard to justice, propriety and benefits for the community.

However, based on the BPK report data in the 2017 Semester I (IHPS) Results still got the findings of problems in the government's financial statements as shown in picture 1: 


\begin{tabular}{|c|c|c|c|}
\hline $\begin{array}{c}\text { Pemerintah/ } \\
\text { Jenis Pemeriksaan }\end{array}$ & $\begin{array}{l}\text { Jumlah } \\
\text { IHP }\end{array}$ & $\begin{array}{l}\text { Jumlah } \\
\text { Temuan }\end{array}$ & $\begin{array}{c}\text { Jumlah } \\
\text { Rekomendasi }\end{array}$ \\
\hline Pemerintah Pusat & 113 & 1.411 & 3.588 \\
\hline Pemeriksaan Keuangan & 102 & 1.322 & 3.330 \\
\hline Pemeriksaan Kinerja & 1 & 11 & 41 \\
\hline Pemeriksaan DTT & 10 & 78 & 217 \\
\hline Pemerintah Daerah & 537 & 7.950 & 21.351 \\
\hline Pemeriksaan Keuangan & 537 & 7.950 & 21.351 \\
\hline BUMN dan Badan Lainnya & 37 & 368 & 998 \\
\hline Pemeriksaan Keuangan & 6 & 45 & 133 \\
\hline Pemeriksaan Kinerja & 8 & 104 & 262 \\
\hline Pemeriksaan DTT & 23 & 219 & 603 \\
\hline Total & 687 & 9.729 & 25.937 \\
\hline Pemeriksaan Keuangan & 645 & 9.317 & 24.814 \\
\hline Pemeriksaan Kinerja & 9 & 115 & 303 \\
\hline Pemeriksaan DTT & 33 & 297 & 820 \\
\hline
\end{tabular}

Source: IHPS BPK RI semester I 2017

Picture-1: Number of LHP, Audit Findings, and BPK Recommendation for Semester I 2017

Can be seen in the table above shows that a significant number of findings found in local government agencies. Thus researchers interested in making the Local Government as the object of this study.

Based on complete data, the BPK report revealed 7,950 findings which contained 12,168 problems, consisting of $6,053(49 \%)$ problems of the Internal Control System (SPI) and 6,115 (51\%) issues of non-compliance with statutory provisions valued at Rp2.08 trillion.

The details of the problem can be summarized, among others, 2,525 (67\%) losses worth Rp1,130 trillion, $413(11 \%)$ potential losses worth Rp419.6 billion and $846(22 \%)$ problems lacking acceptance worth Rp537, 72 billion which happened to the regional government.
For the sake of the realization of transparent financial reporting, the reporting submitted must meet the standards set as regulated in Government Regulation Number 71 of 2010 concerning Government Accounting Standards, stating that the financial statements are prepared to provide relevant information regarding financial position and all transactions carried out by a reporting entity during one reporting period.

Whereas if it is seen based on BPK's opinion on the presentation of Regional Government's financial reporting, the Regional Government Inspection Results reported by BPK in IHPS I 2017 contain examination results on LKPD that have not yet received WTP opinion generally because there are accounts in the financial statements that are presented not in accordance with SAP. The accounts that are presented not in accordance with SAP can be seen in Graph 1:

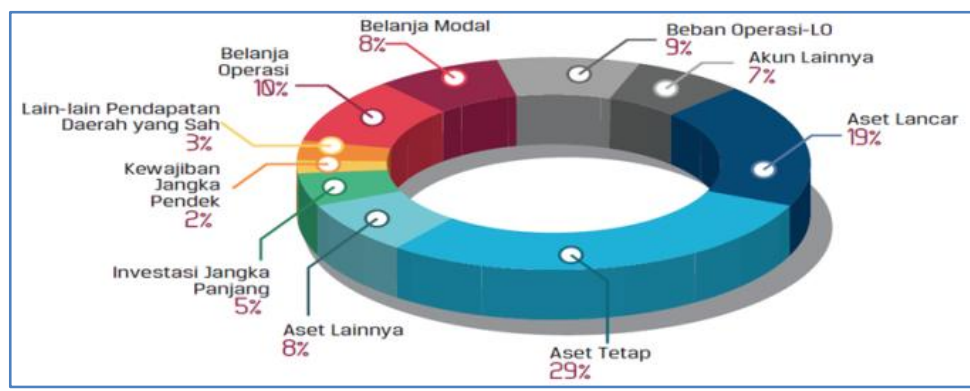

Source: IHPS BPK RI semester I 2017

Graph-1: The Served Account Is Not In Accordance With SAP at LKPD 2016

The three largest accounts and issues that affect the fairness of the 2016 LKPD presentation are as follows:

1. Current assets of 87 regional governments, including the use of cash for the treasury's personal interests, cash overdrawn, receivables not yet presented at the net realizable value, and the presentation of inventory values has not been based on stock taking.

2. Fixed assets at 136 local governments, including land, buildings and buildings, equipment and machinery, as well as roads, irrigation and network 
assets, have not been recorded or recorded as inaccurate and their whereabouts are unknown.

3. Operational expenditure for 48 regional governments, including spending on goods indicated fictitious, expenditure of goods not in accordance with the provisions, as well as expenditure on grants are not accounted for and cannot be traced.

The above phenomenon shows that the financial statements of regional government organizations in Indonesia experience weaknesses in transparency. This is caused by the financial reporting presented not fulfilling SAP as regulated in government regulations. Thus this can be analyzed that the pressure originating from outside the organization in this case is called externally which influences the management to report transparently.

In line with the phenomenon of the influence of external pressures on financial reporting transparency, Nugraha and Henry [1] examined the detection of financial statements through risk, pressure and opportunity factors based on the OJK 2008-2012 press release. The results of his study indicate that external pressures have a positive effect on financial statement fraud. The external pressure factor is a critical factor in determining the quality of accounting information.

The reason for the weak disclosure of financial statement information as explained above based on the data above shows that the commitment has not been fully implemented. The commitment in question is a commitment to present transparent and accountable information to the public in order to increase public trust. The results of Mutia Yesnita's research [2] state that management commitment significantly influences the transparency of financial statements. One form of commitment carried out by the organization is to publish financial reports through mass media as a form of accountability to the public.

Based on the data found in IHPS I 2017 reported by BPK one of the causes is also due to technical constraints due to lack of human resources who have the ability to prepare financial reports correctly and transparently. While the process of recognition, measurement and reporting of accounting has not yet proceeded because it has not been supported by adequate human resources. Viswa Nadham [3] examines the assessment of increased financial statement transparency. The results of his research show that expert skills in financial management affect the transparency of local government financial reporting.

Based on this phenomenon, this study aims to examine and obtain empirical evidence regarding the determinants of Regional Government Financial Reporting Transparency in Tangerang District SKPD, namely external pressure, management commitment and human resource competence.

\section{STUDY OF LITERATURE Study of Literature}

Stakeholder theory is applied in exploring stakeholder influence, focusing on identifying stakeholder needs, and discussing how reporting can meet these needs or not [4]. Stakeholders or also called stakeholders are individuals or groups of people involved in an organization in order to achieve the goals set. Stakeholders in government consist of 2 categories, namely internal and external. Internal scope consists of high state institutions (legislative / executive), management, and employees. While the external scope relates to suppliers, consumers, the community, the environment and others.

From a public relations perspective, quoting from Rachmat [5] stakeholder theory is often used in three theoretical approaches: First, descriptive stakeholder theory. Namely to describe the characteristics and behavior or actual activities undertaken by the organization. Second, instrumental stakeholder theory. Namely understanding how to achieve organizational goals, namely the relationship between stakeholder management strategies and achieving organizational goals such as increasing profits, avoiding lawsuits, and achieving growth. Third, normative stakeholder theory. Namely to design a regulatory regulation for building relationships based on ethical foundations and philosophical principles of the organization, such as developing organizational social responsibility.

External pressure is pressure originating from outside the organization that can affect organizational performance. Rois and Helmi [6] explain that the elements of external pressure consist of micro external environment (directly related) and macro external environment (indirectly related). While financial reporting transparency is a presentation of financial statements that reflects the nature and operation of the company's actual, trustworthy, and disclosure can be understood based on applicable financial reporting standards. Its dimensions include timely disclosure of reliable, adequate, and relevant information for decision making, Rick Hayes et al. [7].

\section{FRAMEWORK}

\section{Effects of External Pressure on Financial Reporting Transparency.}

Financial Reporting Transparency is influenced by external pressures due to forced regulations on certain parties that will cause organizations to practice unwanted things, such as related to the delivery of financial reporting transparency is only a formality. Without thinking about the tasks and objectives carried out more effectively and efficiency. Research conducted by Mutia Yesnita [2] 
results in external pressures in the form of regulations and legislation resulting in the application of financial reporting transparency that is relatively the same in each SKPD.

\section{Effects of Management Commitment on Financial Reporting Transparency. \\ Financial Reporting Transparency is} influenced by management's commitment. The results of previous studies regarding the effect of management commitment to financial reporting transparency conducted by Bhamornsiri [8] show in his research that management commitment influences the disclosure of financial statement transparency. Bhamornsiri [8] examines transparent financial disclosure and SFAS No. 142. The results of his research show that transparent financial disclosures and the adoption of SFAS No.142 depend on company management estimates that cannot be verified and can even increase accounting manipulation.
Effects of Human Resources Competence on Financial Reporting Transparency.

Financial Reporting Transparency is influenced by HR competencies due to human resource competencies are always different for each individual in an organization. the results of previous studies conducted by Aviva and Sugeng [9] show that human resource competencies affect the increase in financial report transparency. The direction of influence is positive, meaning that if the competency of the financial / accounting human resources, both in terms of financial / accounting human resources are competent, the quality of financial statements will also meet the qualitative characteristics.

Furthermore, the relationship between external pressures, management commitment and human resource competence to the transparency of financial reporting can be described as follows:

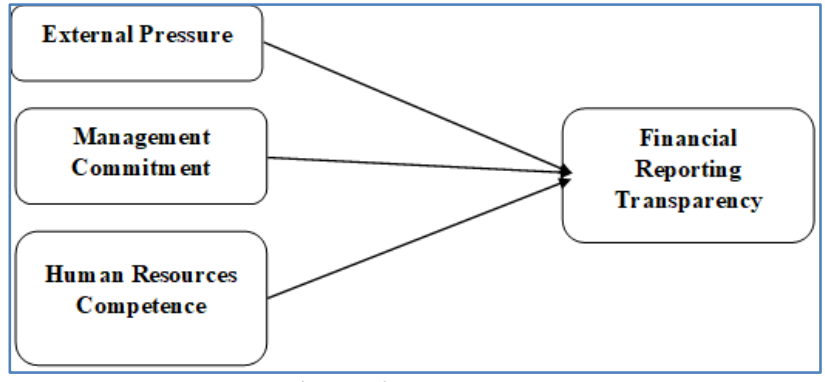

Picture-2: Framework

\section{Formulation of the hypothesis}

Based on this explanation, the following hypotheses can be formulated:

$\mathrm{H} 1=$ External pressure has a positive effect on the financial reporting transparency.

$\mathrm{H} 2=$ Management commitment has a positive effect on the financial reporting transparency.

H3= Human resource competency has a positive effect on the financial reporting transparency.

\section{METHODOLOGHY}

This type of research is a quantitative descriptive causal study by conducting a hypothesis test. Causal research aims to test hypotheses about the effect of one or several variables (independent variables) on other variables (the dependent variable).

The population in this study is the Regional Work Unit or called SKPD which is in the Government of Tangerang Regency. Sampling in this study the authors used a purposive sampling technique, the researchers determine the characteristics of the population concerned and then try to find individuals who have these characteristics to participate in research studies, Johnson \& Christensen [10]. The data collection method is in the form of a survey conducted using instruments in the form of a systematic and structured physical questionnaire.

Data processing will be performed using IBM SPSS Statistics Version 26 software that is used to explain the presence or absence of influence between variables.

\section{RESULT AND DISCUSSION RESULT}

Based on the results of the questionnaire that has been received by researchers, the following profile of respondents is presented in Table 1: 
Table-1: Profile of Respondents

\begin{tabular}{|c|c|c|c|c|c|c|c|}
\hline \multirow{3}{*}{\multicolumn{2}{|c|}{ Profile of Respondents }} & \multicolumn{4}{|c|}{ Gender } & \multirow{2}{*}{\multicolumn{2}{|c|}{ Total }} \\
\hline & & \multicolumn{2}{|c|}{ Man } & \multicolumn{2}{|c|}{ Women } & & \\
\hline & & Amount & $\%$ & Amount & $\%$ & Amount & $\%$ \\
\hline \multirow{3}{*}{ Age } & $<40$ years old & 20 & $23 \%$ & 10 & $11 \%$ & 30 & $34 \%$ \\
\hline & $>40$ years old & 42 & $47 \%$ & 17 & $19 \%$ & 59 & $66 \%$ \\
\hline & Total & 62 & $70 \%$ & 27 & $30 \%$ & 89 & $100 \%$ \\
\hline & & & & & & & \\
\hline \multirow{4}{*}{$\begin{array}{l}\text { Years of } \\
\text { service }\end{array}$} & $<5$ years & 20 & $23 \%$ & 10 & $11 \%$ & 30 & $34 \%$ \\
\hline & $5-15$ years & 30 & $33 \%$ & 10 & $11 \%$ & 40 & $44 \%$ \\
\hline & $>15$ years & 12 & $14 \%$ & 7 & $8 \%$ & 19 & $22 \%$ \\
\hline & Total & 62 & $70 \%$ & 27 & $30 \%$ & 89 & $100 \%$ \\
\hline & & & & & & & \\
\hline \multirow{3}{*}{ Position } & Staff & 20 & $23 \%$ & 10 & $11 \%$ & 30 & $34 \%$ \\
\hline & $\begin{array}{l}\text { Head of } \\
\text { Division }\end{array}$ & 42 & $47 \%$ & 17 & $19 \%$ & 59 & $66 \%$ \\
\hline & Total & 62 & $70 \%$ & 27 & $30 \%$ & 89 & $100 \%$ \\
\hline
\end{tabular}

\section{Descriptive Statistical Analysis}

Descriptive statistics are used to describe data statistically. Descriptive statistics in this study refer to data collected from questionnaires distributed and then tabulated for use as data analysis tools.

\section{Variable Description of External Pressure}

Table-2: Description of External Pressure

\begin{tabular}{|c|l|c|c|}
\hline No & \multicolumn{1}{|c|}{ Indicators } & Mean & $\begin{array}{c}\text { Std. } \\
\text { Deviation }\end{array}$ \\
\hline 1 & Government Regulations & 3,92 & 0,4323 \\
\hline 2 & Executive Institution & 3,91 & 0,4431 \\
\hline 3 & Public & 3,83 & 0,5273 \\
\hline 4 & Economic factors & 3,72 & 0,6569 \\
\hline 5 & Political Factors & 3,67 & 0,8363 \\
\hline 6 & Technological development & 3,78 & 0,5168 \\
\hline 7 & Use of Technology & 3,76 & 0,5843 \\
\hline
\end{tabular}

Source: Primary data processed.

From table 2 it can be explained that the maximum value in the regulatory aspect by obtaining an average value of 3.92 , this illustrates the level of government accounting standards considered financial statement makers difficult to apply, while the standard deviation of 0.4323 illustrates government employees gives an opinion in perceiving relatively uniform regulation.
While the external pressure in the SKPD Tangerang District shows a minimum level of political aspects by obtaining an average value of 3.67 , this illustrates that government empolyees believes that the Regent as the head of the region does not participate in driving the budget for political interests during the election, as for the standard deviation of 0.8363 shows the diversity of opinions in perceiving political factors.

\section{Variable Description of Management Commitment}

Table-3: Description of Management Commitment

\begin{tabular}{|r|l|c|c|}
\hline No & \multicolumn{1}{|c|}{ Indicators } & Mean & $\begin{array}{c}\text { Std. } \\
\text { Deviation }\end{array}$ \\
\hline 1 & $\begin{array}{l}\text { Management } \\
\text { Character }\end{array}$ & 3,53 & 0,6757 \\
\hline 2 & $\begin{array}{l}\text { Management } \\
\text { Obiectives and }\end{array}$ & 3,73 & 0,6702 \\
\hline 3 & $\begin{array}{l}\text { Management } \\
\text { Responsibilities }\end{array}$ & 3,69 & 0,6842 \\
\hline 4 & $\begin{array}{l}\text { Work Management } \\
\text { Productivitv }\end{array}$ & 3,75 & 0,6446 \\
\hline 5 & Management Needs & 3,75 & 0,6620 \\
\hline
\end{tabular}

Source: Primary data processed. 
From Table 3 it can be explained that the value of the maximum level in the aspect of work productivity in agencies by obtaining an average value of 3.75 , it illustrates that goverment employees already has a high awareness to settle because of basic needs. By respecting and obtaining good judgment from management and being flexible and easily adjusting to changes, the standard deviation of 0.6446 illustrates that goverment employees give an opinions in perceiving work productivity in relatively uniform institutions.
Whereas the commitment of management in the SKPD Tangerang District shows a minimum level of aspects of management character by obtaining an average value of 3.53 , it illustrates that the emotional attachment and involvement of goverment employees in the SKPD Tangerang District has not been fully motivated to carry out their duties in collaboration in teams as public servants responsible for the community, while the standard deviation of 0.6757 shows the diversity of opinions in perceiving the character of management within the agency.

\section{Variable Description of Human Resource Competence}

Table-4: Description of Human Resource Competence

\begin{tabular}{|c|l|c|c|}
\hline No & \multicolumn{1}{|c|}{ Indicators } & Mean & Std. Deviation \\
\hline 1 & $\begin{array}{l}\text { Skills possessed about } \\
\text { understanding tasks }\end{array}$ & 3,92 & 0,5482 \\
\hline 2 & $\begin{array}{l}\text { Expertise in } \\
\text { Government } \\
\text { Accounting Standards }\end{array}$ & 3,94 & 0,5510 \\
\hline 3 & $\begin{array}{l}\text { Expertise in financial } \\
\text { statements procedure }\end{array}$ & 3,92 & 0,5686 \\
\hline 4 & Education pursued & 3,96 & 0,5821 \\
\hline 5 & $\begin{array}{l}\text { The purpose of the } \\
\text { employee }\end{array}$ & 4,00 & 0,5222 \\
\hline
\end{tabular}

Source: Primary data processed.

Based on Table 4 it can be explained that the maximum value on the aspect of employee objectives by obtaining an average value of 4.00 , this is due to the thought or constant basic intentions that encourage individual goverment employees to act have the goal of achieving financial reporting quality that makes a reference the level of performance of an agency, while the standard deviation of 0.5222 indicates the diversity of opinions in perceiving the goals of each employee in SKPD Tangerang District.
While the aspect of knowledge possessed by SKPD Tangerang District employees obtained a minimum average value of 3.92 , this illustrates that information owned / controlled by employees is not fully understood to the maximum regarding the procedure for recording financial statements, while the standard deviation of 0.5686 indicates the diversity opinion in perceiving employee knowledge of procedures, accounting policies and financial reporting.

\section{Variable Description of Financial Reporting Transparency}

Table-5: Description of Financial Reporting Transparency

\begin{tabular}{|c|l|c|c|}
\hline No & \multicolumn{1}{|c|}{ Indicators } & Mean & Std. Deviation \\
\hline 1 & Honest Presentation & 4,42 & 0,6362 \\
\hline 2 & Verifiability & 4,22 & 0,6528 \\
\hline 3 & Accurate and on time & 4,27 & 0,6530 \\
\hline 4 & Government Accounting Standards & 4,29 & 0,6068 \\
\hline 5 & Internal Control System Standards & 4,27 & 0,5986 \\
\hline 6 & Feedback value & 4,28 & 0,6028 \\
\hline 7 & Predictive value & 4,34 & 0,5210 \\
\hline 8 & Completeness & 4,30 & 0,5519 \\
\hline
\end{tabular}

Source: Primary data processed.

Based on Table 5 it can be explained that the maximum value in the aspect of honest presentation in financial reporting by obtaining an average value of 4.42, this indicates that the information honestly describes transactions and other events related to the budget that have been issued have been presented fairly, as for standard deviation of 0.6362 indicates the diversity of opinions in perceiving honest presentation in the financial statements.

Whereas aspects of financial statements can be verified by other institutions obtaining a minimum average value of 4.22 , this illustrates the information presented in the financial statements at the SKPD 
Tangerang District has not been fully tested or verified, because the EPIKD Directorate as the manager of SIKD does not always verify financial reporting that has been submitted online system. As it should be stated in PMK Number 188/PMK.05/2018 article 7 paragraph 3 reads, verification of data and financial information of the regional government is carried out by the Directorate of EPIKD as the manager of SIKD, while the standard deviation of 0.6528 shows the diversity of opinions in perceiving verification financial report data conducted by the EPIKD Directorate.

\section{Data Quality Test}

\section{Validity Test}

Table-6: Validity test

\begin{tabular}{|c|c|c|c|c|}
\hline Variable & $\begin{array}{l}\text { Indik } \\
\text { ator }\end{array}$ & $\begin{array}{c}\mathbf{R} \\
\text { Calcul }\end{array}$ & $\begin{array}{c}\text { rTab } \\
\text { le }\end{array}$ & Desc. \\
\hline \multirow{7}{*}{$\begin{array}{l}\text { External } \\
\text { Pressure }\end{array}$} & 1 & 0,501 & 0,213 & Valid \\
\hline & 2 & 0,535 & 0,213 & Valid \\
\hline & 3 & 0,732 & 0,213 & Valid \\
\hline & 4 & 0,811 & 0,213 & Valid \\
\hline & 5 & 0,777 & 0,213 & Valid \\
\hline & 6 & 0,731 & 0,213 & Valid \\
\hline & 7 & 0,780 & 0,213 & Valid \\
\hline \multirow{5}{*}{$\begin{array}{l}\text { Management } \\
\text { Commitment }\end{array}$} & 1 & 0,723 & 0,213 & Valid \\
\hline & 2 & 0,784 & 0,213 & Valid \\
\hline & 3 & 0,887 & 0,213 & Valid \\
\hline & 4 & 0,899 & 0,213 & Valid \\
\hline & 5 & 0,850 & 0,213 & Valid \\
\hline \multirow{5}{*}{$\begin{array}{c}\text { HR } \\
\text { Competence }\end{array}$} & 1 & 0,872 & 0,213 & Valid \\
\hline & 2 & 0,864 & 0,213 & Valid \\
\hline & 3 & 0,899 & 0,213 & Valid \\
\hline & 4 & 0,852 & 0,213 & Valid \\
\hline & 5 & 0,850 & 0,213 & Valid \\
\hline \multirow{8}{*}{$\begin{array}{c}\text { Financial } \\
\text { Reporting } \\
\text { Transparency }\end{array}$} & 1 & 0,786 & 0,213 & Valid \\
\hline & 2 & 0,899 & 0,213 & Valid \\
\hline & 3 & 0,905 & 0,213 & Valid \\
\hline & 4 & 0,904 & 0,213 & Valid \\
\hline & 5 & 0,920 & 0,213 & Valid \\
\hline & 6 & 0,895 & 0,213 & Valid \\
\hline & 7 & 0,872 & 0,213 & Valid \\
\hline & 8 & 0,925 & 0,213 & Valid \\
\hline
\end{tabular}

Source: Primary data processed with SPSS 26.

Based on the results of the validity test in table 6 above, the $\mathrm{R}$ calculation results are greater than the $\mathrm{R}$ table overall. Thus the questionnaire items in this study are valid and can be used.

\section{Reliability Test}

Table-7: Reliability Test

\begin{tabular}{|c|c|c|}
\hline Variable & $\begin{array}{c}\text { Cronbach's } \\
\text { Alpha }\end{array}$ & $\begin{array}{c}\text { N of } \\
\text { Items }\end{array}$ \\
\hline External Pressure (X1) &, 823 & 7 \\
\hline $\begin{array}{c}\text { Management } \\
\text { Commitment (X2) }\end{array}$ &, 885 & 5 \\
\hline HR Competence (X3) &, 917 & 5 \\
\hline $\begin{array}{c}\text { Financial Reporting } \\
\text { Transparency (Y) }\end{array}$ &, 961 & 8 \\
\hline
\end{tabular}

Source: Primary data processed with SPSS 26.

While the reliability test in table 7 above, gives a Cronbach's alpha value> 0.60 for all variables per questionnaire item. Thus also the questionnaire items in this study are reliable and can be used. 


\section{Hypothesis Testing}

Table-8: Determination Test (R2)

\begin{tabular}{|r|c|c|c|}
\hline $\begin{array}{r}\text { Mo } \\
\text { del }\end{array}$ & $\mathbf{R}$ & R Square & $\begin{array}{c}\text { Adjusted R } \\
\text { Square }\end{array}$ \\
\hline 1 & $.535^{\text {a }}$ & .286 & .261 \\
\hline \multicolumn{4}{|c|}{ F Test } \\
\hline \multicolumn{5}{|c|}{ Model } & F & Sig. \\
\hline \multirow{2}{*}{1} & $\begin{array}{c}\text { Regressi } \\
\text { on }\end{array}$ & 11.355 & $.000^{\mathrm{c}}$ \\
\cline { 2 - 4 } & & & \\
\hline
\end{tabular}

T Test

\begin{tabular}{|c|c|c|c|c|}
\hline \multicolumn{2}{|c|}{ Model } & $\begin{array}{c}\text { Unstandardized Coefficients } \\
\text { B } \\
\end{array}$ & $\mathbf{t}$ & Sig. \\
\hline \multirow[t]{4}{*}{1} & (Constant) & 11.397 & 2.729 & .025 \\
\hline & External Pressure & .595 & 4.639 & .005 \\
\hline & $\begin{array}{l}\text { Management } \\
\text { Commitment }\end{array}$ & .110 & 1.065 & .154 \\
\hline & HR Competence & .267 & 1.938 & .219 \\
\hline
\end{tabular}

Table 8 shows the value of $\mathrm{R}$ or multiple correlation of 0.535 then $\mathrm{R}$ Square of 0.286 with the value of Adjusted R Square: $0.261<0.5$ or $<50 \%$ then shows that a set of independent variables together are able to explain the dependent variable significantly but weakly, that is equal to $26.1 \%$, while the rest $100-26.1$ $=73.9 \%$ is explained by other variables outside the independent variables studied.

The ANOVA test data obtained a Fcount of 11,355 with a probability of 0,000 . Probability value is much smaller than 0.05 so it can be concluded that, External Pressure, Management Commitment and Human Resources Competence simultaneously affect the Transparency of Financial Reporting.

It can be seen the influence of the relationship of exogenous latent variables to endogenous variables can be explained as follows:

1. The path parameter coefficient value obtained from the influence of external pressure (X1) on financial reporting transparency $(\mathrm{Y})$ is 0.595 (positive) and $\mathrm{P}$ Values $(0.005)$ is less than 0.05 , which means there is a positive and significant effect.

2. The path parameter coefficient value obtained from the effect of management commitment (X2) on financial reporting transparency $(\mathrm{Y})$ is 0.110 (positive) and $\mathrm{P}$ Values $(0.154)$ is greater than 0.05 , which means there is no influence and is not significant.

3. The path parameter coefficient value obtained from HR competence (X3) on financial reporting transparency $(\mathrm{Y})$ is 0.267 (positive) and $\mathrm{P}$ Values $(0.219)$ is greater than 0.05 , which means there is no influence and is not significant.

\section{DISCUSSION}

Effects of External Pressure on Financial Reporting Transparency.

The results of the study conducted by the author indicate that the cause of the lack of transparency of information in the Regional Government is due to the element of external pressure from each SKPD, namely the micro element where there are government regulations that govern regional financial reporting standards which are considered too complex and complicated. So that regional financial statement makers cannot compile transparently according to Government Accounting Standards as regulated in Government Regulation Number 71 of 2010 concerning Government Accounting Standards.

External pressure has a positive effect on Transparency of Financial Reporting on the micro element in this case supported by research of Manuel Pedro et al. (2013) which states that external pressure in the form of financial standard bodies has an important influence on public sector accounting reforms implemented to improve accountability and transparency of public finances. This shows that according to the theoretical study of Institutional Theory where in this case the legislative party has an institutional presence in carrying out legislative, budgetary and supervisory functions in accordance with the law on executive performance in local governments.

The information asymmetry that is emphasized on the lack of transparency in financial reporting in this study, proved to contain agency theory or agency theory where there is a contract between government officials who are elected and appointed as agents in the SKPD and voters (the public) as the principal. Agency theory that occurs in this study, is that officials in the regional government as the party who conducts financial reporting to the public have more information so that 
they can make decisions or policies that are possible that only concern the government and ignore the interests and welfare of the people.

\section{Effects of Management Commitment on Financial Reporting Transparency.}

In this study no relationship was found between Management Commitment and Financial Report Transparency. That is because even though the units have good work productivity in the agency is considered to have no effect on the application of Financial Reporting Transparency.

This is not in line with previous research conducted by Mutia Yasnita [2] which states that management commitment has a positive effect on the application of transparency. One form of commitment carried out by the organization is to publish financial reports through mass media as a form of accountability to the public.

\section{Effects of Human Resources Competence on Financial Reporting Transparency.}

Researcher found no relationship influence between the of HR competencies on financial reporting transparency. This researcher believes that all capacities possessed by financial officers of each SKPD and the achievement goals in the quality of financial reporting that makes a reference to the level of performance of an agency, is considered to have nothing to do with financial reporting transparency carried out by each SKPD. This is possible because the application of transparency cannot depend on an human resources capacity or competency.

These results are not in line with the results of previous studies conducted by Aviva et al. [9] Which argues that human resources competence affects financial reporting transparency because the capacity of human resources is the ability of a person or individual, an organization (institution), or a system to carry out its functions or authorities to achieve its objectives effectively and efficiently? Quality must be seen as the ability to achieve performance, to produce outputs and outcomes.

\section{CONSLUSIONS AND SUGGESTIONS Conslusions}

This study examines the influence of External Pressure, Management Commitment and HR Competence on Financial Reporting Transparency. From the results of the discussion in this study, the conclusions are as follows:

1. External pressure has a positive and significant impact on financial reporting transparency. This is seen by the pressure from government regulations regarding the obligation to apply Government Accounting Standards proven to influence the makers of financial statements in the application of transparency.
2. Management commitment does not affect the transparency of financial reporting. That is because even though the units in the SKPD have a commitment to good work productivity within the agency they are judged to have no effect on the application of financial reporting transparency.

3. Human resources competence does not affect the transparency of financial reporting. This is because the application of financial reporting transparency cannot be influenced by an individual's capacity or competence of each financial statement maker in each SKPD in Tangerang District.

\section{SUGGESTIONS}

1. For the management of SKPD in Tangerang District units, in order to be able to make regulations concerning sanctions as a preventive and repressive measure, as well as to function as guarantees for compliance with the Law on the State Budget / Regional Regulations. So that budget information can be transparent.

2. For further researchers, in order to add other indicators in assessing the causes that influence the application of financial reporting transparency such as the Internal Control System and Environmental Uncertainty so that it can further strengthen the results of research produced.

\section{REFERENCE}

1. Novi, Dwi Aditya N., \& Deliza, H. (2015). Pendeteksian Laporan Keuangan Melalui Faktor Resiko, Tekanan Dan Peluang. e-Journal Akuntansi Trisakti, 2(1), $29-48$.

2. Yesnita, M., Desmiyawati, D., \& Kurnia, P. (2016). Pengaruh Tekanan Eksternal, Komitmen Manajemen dan Sistem Pengendalian Internal Pemerintah terhadap Penerapan Transparansi Pelaporan Keuangan Pemerintah Daerah (Studi Empiris pada Pemerintahan Kota Bukittinggi) (Doctoral dissertation, Riau University).

3. Nadham, Viswa N. (2016). Assessment of Enhancing Transparency of Financial Statements. International Journal of Accounting and Financial Reporting, 6( 2).

4. Harrison, J. S., Barney, J. B., Freeman, R. E., \& Phillips, R. A. (Eds.). (2019). The Cambridge handbook of stakeholder theory. Cambridge University Press.

5. Kriyantono, R. (2017). Teori-Teori Public Relations Perspektif Barat \& Lokal: Aplikasi Penelitian \& Praktik. Kencana.

6. Rois, A., \& Helmi, M. (2016). Pengantar Manajemen. Jatim: Penerbit Empatdua Kelompok Intrans Publishing.

7. Hayes, R., Wallage, P., \& Gortemaker, H. (2014). Principles of auditing: an introduction to international standards on auditing. Pearson Higher Ed. 
Jafril Yudin \& Wiwik Utami; Saudi J Bus Manag Stud, July., 2020; 5(7): 370-379

8. Sevin, S., Schroeder, R., \& Bhamornsiri, S. (2007). Transparent financial disclosure and SFAS No. 142. Managerial auditing journal.

9. Masruroh, A. F., \& Praptoyo, S. (2015). FaktorFaktor Yang Mempengaruhi Transparansi Laporan Keuangan Pemerintah Kota. Jurnal Ilmu dan Riset Akuntansi, 4(7), 1-20.
10. Johnson, R. B., \& Christensen, L. (2019). Educational research: Quantitative, qualitative, and mixed approaches. SAGE Publications, Incorporated.

11. Indonesia, R. (2004). Undang-Undang Republik Indonesia Nomor 32 Tahun 2004 Tentang Pemerintahan Daerah. Jakarta (ID): RI. 